\title{
Educational Process and Personality of the Educator
}

\section{Lenka Pasternáková - Gabriela Sláviková *}

\begin{abstract}
The paper is focused on the personality of an educator and the demands placed on him/her.

Key words: education, learning process, teacher, teacher's personality.
\end{abstract}

The term "personality" and its definition are the subject of several scientific disciplines, especially the psychology. Psychologists define the concept of personality in a variety of terms. D. Kováč (1985) defines it as psychological reality consisting of biological and social components; some other authors define it as a system regulating relations between a man and the world. Personality is scrutinized also by other scientific disciplines, such as philosophy, sociology and pedagogy. In pedagogy, personality is generally understood as a point of departure, a condition and an objective of education with particular regard to the comprehensive development of an individual. More specific definitions are based on the knowledge of differential psychology and embrace personality as a set of psychological qualities and traits. Other definitions are based on the social nature of a man and define personality as a set of social roles and relations. The concept of personality is also in the centre of ethics, biology, legal sciences, etc.

The complexity of personality structure is manifested in its external and internal characteristics:

External characteristics show the phenomenal part of personality and are observable in individual acts, behavior, deeds and responses to external stimuli.

Internal characteristics, congenital as well as learned, under which an individual is acting in a particular situation in a certain way, are manifested in human actions, and verbal or written expressions. To sum up, the manifestations of personality reveal the characteristics, which should be, especially for educators, formed as early as during school years, job-training years as well as during the professional career. The focus shall be on creativity, professionalism, physical condition, mental preparation, autonomy and assertiveness. Establishment of these preconditions brings changes into the system of training of educators at all levels and types of educational institutions.

To determine the role of an educator among educational factors is extremely difficult. Not everybody meets the required criteria. An educator shall be only a person with relevant knowledge, positive personal and moral characteristics, and dignified personal life and behaviour. Moreover, the person shall have a positive relation to children, youth and educational work. Therefore, the personality of an educator shall meet the following requirements:

In the field of general training, which is the result of an appropriate type and level of education and constantly replenished by self-education.

In the field of specialized training, which includes necessary knowledge on pedagogy, psychology, theory of education outside the classroom, appropriate physical training and disposition, cultural and

\footnotetext{
* Lenka Pasternáková, Dubnica Technological Institute, Dubnica nad Váhom, Slovakia; pasternakova@dti.sk Gabriela Sláviková, Dubnica Technological Institute, Dubnica nad Váhom, Slovakia; slavikova@dti.sk
} 


\section{Acta Technologica Dubnicae \\ volume 2, 2012, issue 2}

philosophical orientation, etc. The training is internally divided into the theoretical and practical training.

In the field of specific preparation for educational activities we emphasize the ability to set up primary educational objectives, ability to implement them, continuously diagnose educational activities and correct further educational activities accordingly.

An educator shall be primarily an educational authority. An educator is considered to be such an authority that s/he effectively manages to influence individuals as well as a group of children or young people. The most important precondition of an authority is a constructive, organizational, communicative and diagnostic activity.

The personality of an educator is influenced by such factors as age, sex and temperament. It is wise to have various types of educators with different predispositions for different types of activities. Then they complement each other and they are able to sustain various types of educational activities, be patient, distribute reassurance and solve the problems thoughtfully, timely and fairly (Višňovský Kačáni, 2001).

This profession is a great challenge and can be handled only by educators with a deliberately planned system of educational activities, applying diverse methods, forms and means; those who act as actual authorities by their personal example, gestures and words. An educator should act as a personality in every situation, be a good example and a coordinator of educational influences; he should be able to act assertively and argument pedagogically and should not be manipulated by anyone. An educator should be self-disciplined, enthusiastic, sincere and self-reflexive, if needed. He should not fall prey to scepticism and despair.

Carrying out the work of an educator takes, in addition to high professionalism and self-control, also the respect for moral principles. Ethical behavior presupposes the respect for the self, for the others, empathy and ability to take the others' interests and needs into consideration when making a decision. Professional ethical approach of an educator means to apply general moral principles and educators should master:

- verbal communication,

- principles of conflict-free communication,

- principles of good manners,

- ability to gain confidence of the educated,

- closely follow the standards,

- be confident about their work,

- be willing to study,

- have a sense of justice.

The concept of an authority is of multiple meanings. Its understanding and theoretical definition in different pedagogical systems vary. In the terminological dictionary Andragogika (Andragogy) (2000, p. 57) the authors provide the following definition of the concept: Authority (lat. auctor = guarantor, role model, example, teacher, master, founder, creator, auctoritas = warranty, seriousness, powerful /influential/ person, power, influence).

- One of the fundamental forms of power implementation based on the general acceptance of influential eligibility of a certain personality, group of people or an institution.

- (psychol.) Respected seriousness of the personality provided by their exceptional, mostly leading position in the hierarchy of a social status (formal), or by exceptional personal qualities or merits (informal) as recognition of their dominance and superiority.

- (ped. and andr.) Respecting the position of a teacher and a lecturer based on formal recognition of their professionalism, knowledge, and experience as well as the tact. 


\section{Acta Technologica Dubnicae \\ volume 2, 2012, issue 2}

The authority is regarded according to the acknowledged role of an individual, an institution or an organization based on their experience, knowledge, professional and social activities and high performance and organizational skills. It may be manifested:

a) As an influence of a group or an individual in various areas of social life which is granted on the basis of something extraordinary. The concept of authority in social psychology is identical with the concept of power.

b) Recognition of the right of an individual to make decisions in situations which are important for certain groups or individuals. In this case, it is based on strong personal preference.

Personal authority in the educational process arises from the actual personality of a teacher, from recognized personal and mental qualities, which are, in some ways, of extraordinary quality. These qualities are education, modesty, willingness to help, ability to manage work on a quality level, to create good interpersonal relations, etc.

The factors defining the boundaries between authority, power and influence are usually the following criteria:

a) From the position of an authority the orders are carried out willingly; from the position of power, the orders are executed even despite the resistance.

b) Authority and influence share a common feature - volunteerism.

c) Legitimacy - when recognised, authority and power become an obligation.

Authority is a significant social factor operating within the field of control and social integration (disintegration) and significantly influences the leadership of people. The most primitive form of authority is physical power and the highest form of authority is spontaneity, free and voluntary subordination. Various forms of coercion (physical, economical) and various forms of manipulation (reward system, salary, benefits, conditions of promotion) create common conditions for achievements of an individual (elements of power of creating authority). More detailed analysis distinguishes personal authority (natural, primary), functional authority (professional) and positional authority (formal, secondary). The most commonly recognizable authority is the formal one, which derives from the position of a lecturer (teacher) and his/her role in the organizational or social structure, and informal authority, which is determined by specific qualities, such as talent, education, qualification and tact of a particular personality.

According to A. Vališová (1998) the concept of authority can also mean a possibility to manage, manipulate opinion, command respect, affect character of people, authorities, states or it may mean also moral and spiritual superiority, but also claiming the trust and subjugating other people. She sees the term authority synonymous to the following terms: management, dominance and competence. In her opinion, if a person has the authority, it is possible to recognize their superiority and then subject to them. Superiority derives from the accumulated possession, official position, ancestry, ancient glory, or it is based on exceptional wisdom, talent, thoughtfulness, scholarship and the like. According to A. Vališová (1998), the concept of authority had been developing during the ages from the external and derived authority, related to the sacred authority, to the internal and rationalised authority. Today, the educational approaches rely on voluntarism and the growth of inner conviction. They count more on subordination of a pupil to an educator in a non-violent way. Authority shall no longer be enforced. However, there are voices warning against the possible extremism of such approaches - the anarchy.

Authority means seriousness and respect that some of the parents and educators and a few other people experienced - those, who strongly influence a child or an adult and to whom they voluntarily subordinate. It is based on the awareness of their knowledge, experience, moral strength, strength of a character, consistency of procedures and the way of treating other people. 


\section{Acta Technologica Dubnicae \\ volume 2, 2012, issue 2}

Authority of each individual arises mainly from their own personalities, i.e. their moral and character qualities, experience and knowledge. Some people believe that authority is given to parents; that they have inherited it; they do not perceive it as a personal gift, a talent which cannot be learnt or taught. Modern psychology provides a relatively precise definition of an authoritarian personality and their qualities. Despite the fact that it is an individual and not a general quality, we can state that it is possible for each parent and educator to gain authority with children, if one puts the appropriate efforts in it and acts accordingly.

G. Petty (1996) believes that good relations between an educator and an educated are based on mutual respect. In his view, the educated respect and appreciate mainly personal qualities of their educators, such as skills, knowledge and professionalism. An educator with authority honours each individual in their charge and appreciates all efforts to positive change. According to G. Petty (1996), it is extremely important to realize that mutual respect is not rooted only in a kind of universal respect towards the collective as a whole but in an educator's respect of each individual. Similarly, we can fully agree with the other claim: before there is a relation established, there must past a certain period of time, in which an educator usually passes through two stages. In the first stage, the educator achieves a certain power and position based on their institutionalized roles. In this stage, it is the formation of formal authority arising from the position of power, which is legitimate, determined by the formal status and powers vested into the function by an institution. The second stage means the formation of informal authority, which is the result of personality profile, maturity, skills, reasonable amount of confidence and behaviour which provides credits for the person.

Formal authority is inevitable for establishing a normal life within the society. People simply accept that. People usually do not closely examine, for instance, the personality of a guard who controls the traffic at the intersection neither must they personally know the author of a mushroom guide but still they believe their claims and follow their advice. The true authority is established by the issues of moral, ideology, criteria of a value system and relations as these give the sense to human activities and roles. Such is the authority of educators, parents, judges, politicians and others. Neither children nor adults accept the authority blindly. Even children before they acknowledge and accept the authority and subdue to somebody that commands them, try to know the person better and evaluate them. They believe they have the right to evaluate and judge the adults who manage their behavior and actions and of those they meet with, their parents including, and they show respect only to those people who deserve it.

A. Vališová (1998) argues that the authority of educator can be classified into several types or kinds. We distinguish true and apparent authority, where the true authority is obligingly accepted by the subordinates, and the group authority is characterized by permanence and cohesion even in the crisis situations. The apparent authority seemingly does not exist and the subordinates manifest unwillingness to cooperate despite the existence of symbols and recognition of the institution. Such a person has no support from them. A. Vališová (1998) also distinguishes personal authority, positional authority and functional authority. The personal authority represents a natural influence rooted in personal qualities; positional authority is defined by official and institutional status and functional authority is obtained by following expectations of the others - superiors and subordinates.

In addition to the mentioned authority types, A. Vališová (1998) recognizes formal and informal authority. She also mentions formation of statutory authority, charismatic authority, professional authority and moral authority. Statutory authority is identical with the formal and the positional ones, i.e. it is formed by power and position in an institutional hierarchy. Charismatic authority is formed by our image and radiated energy, our attitudes, self-confidence, communicative skills, kindness and tact. Its development is conditioned by true and sincere relation to people. Professional authority develops within the level of our professional knowledge and skills. Moral authority develops by honest relation to the self, the others and the world. It is embodied in the strength of character and humanity within the men. The appropriate combination of all authorities creates universal authority. The authority of an educator is defined as a set of qualities evoking the confidence in the educated. Externally, it is 


\section{Acta Technologica Dubnicae \\ volume 2, 2012, issue 2}

manifested in education, insights, opinions, character, behavior, personal life, moral integrity and positive approach to people.

L'. Višňovský (1998, p. 104) states the most universal preconditions for an authority as follows:

- Constructive activities, which involve tasks related to the content of education, mainly the level of acquired knowledge.

- Organizational activities as a system of skills providing inevitable activity, coordination and cooperation with the educated in organizing activities, including the ability to choose correct forms, methods and means in order to achieve the set objectives.

- Communication with the educated on verbal and non-verbal level.

- Ability to diagnose an individual and a group based on the detailed knowledge of diagnostic methods as well as the ability to use the diagnosis for further optimization of their career.

Educators cannot expect its charge to fall for them at first sight. According to G. Petty (1996), it does not matter whether educators like it or not, they must establish the relationship with their charge on the formal basis based on their legitimate social status. Based on their social status, educators are entitled the obedience of their charge in the matters of behavior. The use of formal authority depends on the conditions under which an educator works. In order to be a respected authority among their charge, educators must apply it with certainty; there is no second chance to make the second "first" impression. Taking the advantage of the power vested in them by their formal status, they should try to act confidently and calmly and give the impression that they are the masters of the situation, especially if it is not quite true. They should act emphatically and peacefully.

B. Kosová (2000, p. 95) also distinguishes between formal and informal authority. Formal authority is rooted in the position of social hierarchy, that is, in the educator's role. Therefore this authority should be applied verbally and non-verbally with confidence, for instance, by a confident voice, actions, posture, issuing orders with certainty, not making pupils see that they managed to disturb an educator's balance. Formal authority shall be applied immediately since the beginning of the work with pupils.

B. Kosová (2000) relying on G. Petty $(1996$, p. 78) further argues that the forces of teacher's orders will not rise by the raise in the intensity of their voice or anger but by following these principles:

- close proximity (entering the personal space of a pupil),

- eye contact (look right in the eye),

- asking questions (a suitable question is better than lecturing).

Informal educational authority - according to B. Kosová (2000) - is rooted in the very personality of an educator. It is a free recognition of superiority of a person in a particular area and its positive evaluation by pupils. According to the experts, the most significant factor is showing the true interest in the work of pupils, their interests and individuality but without trying to become one of them. It can be achieved, for instance, by the following:

- Addressing pupils by their names, asking them politely, expressing thanks.

- Knowing each pupil in details, communicating with them individually, and being interested in their feelings, opinions and interests.

- Rewarding individual contributions of a pupil, their effort to learn, and by mocking no one.

- Setting up clear rules and following them strictly.

- Being a professional in one's work, well-prepared, on time and by finishing the class on time.

- Being equipped with patience and humor and by staying cool. 


\section{Acta Technologica Dubnicae \\ volume 2, 2012, issue 2}

Creating personal authority is not about establishing a too intimate relationship with pupils. Pupils do not need another confidant, they are satisfied with those they have among their peers; they need somebody to be truly interested in them; somebody who is able to provide them with a supportive hand if they need it.

C. Czapów (1981) believes that in many cases the successful fulfilment of educational objectives lies in the fact that educators act not only in the role of formal group leaders but mainly in the role of natural leaders of their charge. In case of formal leadership, the educator's role is rooted in the fact that his/her position in the group is officially approved. On the contrary, if a group is willing to follow the instructions of a certain person for his/her personal qualities regardless of the official position, then it is the natural leadership. To become such a natural leader, it is necessary for the group to get to know the educator's personal value system and so they would recognize his/her leadership. The opportunity to become a formal and in parallel a natural leader does not completely depend only on the personal qualities of an educator but also on his/her social status in a particular group, institution or a society. The higher is the position, the higher the probability to win the educationally important leadership. An educator can lose the authority if there is a discrepancy between what he/she says and what he/she does or if he/she is unfair, vengeful and suffers from other negative traits.

According to B. Kosová (2000), the concept of educational style means the way an educator manages the educational process, the requirements the pupils shall fulfill and the space he provides for pupils' individual work and their personal development. B. Kosová (2000) believes that it is good for an educator to be a flexible type able to change his/her style with regard to the situation but mainly with regard to children's engagement and their personal orientation and receptiveness. Implementation of a particular style depends on educator's personality, personalities in the group, their maturity, particular situation, activity types and tasks. Sometimes, it happens that an educator, due to his/her predispositions, is not able to implement democratic or liberal style; therefore, if one wants to become an educator, he/she needs to know oneself very well.

\section{S. Rys (1975, p. 38-39) lists three types of educational styles:}

- Authoritative style in case of which a very limited amount of freedom for pupils in their individual work and activities is typical; they must follow teacher's instructions with no objections. The class is clearly centred on the teacher, he/she alone is the centre of everything; pupils ask him/her all their questions and only he/she is the one to provide the correct answer and explanation. Teacher applying the authoritative style often suffers from fear and inner uncertainty of pupil's "disobedience". He/she faces it by establishing "iron order", he/she punishes every active attempt of pupils to step outside the established set of instructions and processes; by doing so he/she usually not only prevents any individual work of pupils but also hinders the development of their thinking. Such teaching style causes mental instability of pupils and their learning disabilities.

- Democratic style of teaching creates optimal conditions for learning. This teaching style enables pupils to work individually in accordance with their own consideration or the class subjects to the authoritative instruction on what to do and what to continue with. Pupils incline to significant substantial attitude much more which leads to joint problem solving. A criterion for teacher's democratic behavior is his/her readiness and ability to inspire the pupils in active work and cooperation, and, at the same time, the teacher is considered to be a part of working collective. The teacher and pupils are interconnected through the educational objectives. The objective is not defined by instruction nor does it interfere with closely specified curriculum. Pupils' motivation is truly centred on educational issues; pupils participate in "democratic" educational process because of their own inducements; they do so not only in selection of study materials but also in the selection of methods and procedures by which they intend to reach the goals. Though the teacher does not select the procedures and methods, he/she does not leave it within the pupil's competence (e.g.: he/she 


\section{Acta Technologica Dubnicae \\ volume 2, 2012, issue 2}

does not allow them to choose procedures "blindly" on the principle of trial and error). These methods are selected in the process of common discussions and dialogues within the classroom, in which the exact order of procedures and their applications is stated and appropriate methods are selected regarding all introduced proposals and views. This teaching style prevents the occurrence of possible frustrations and learning disabilities, which can occur due to the teacher's teaching style.

- Liberal style is a style in which the teacher does not interfere with the pupil's activities and is rather docile. This style belongs to "negative education", i.e. the trust to the immanent wisdom and impossibility to influence developmental process of children. It also happens to be the expression of teacher's resignation to given working condition or the expression of his/her laziness and irresponsibility. An attempt to record such an approach is almost impossible, because, in direct observation, the teacher camouflages it by pretended business as the reaction to the classroom situation due to the presence of the observer in the classroom (e.g.: the discipline in the classroom). In case of this style the teacher is more like a passive observer than an active leader. Pupils receive only little help in their study but they have a vast opportunity to mutual distraction. This management of classroom causes chaos, distraction and disintegration. The result is general unwillingness of pupils to study, their mental indifference followed by related learning disabilities.

The analysis and observation of the educational process management show that the level of this management is mainly conditioned by the personality of teacher being the subject and condition thereof. Let us use the words of a Russian pedagogue K. D. Ušinskij (in Kominarec, 2006): "in education, everything must be based on teacher's personality because the educational power originates only in living source of human personality. No schedule, no curriculum, no artificially enforced system, even if they are overly ingenious, can replace the personality in education. The teacher's influence is the educational power, which cannot be replaced neither by textbooks nor moral mentoring or the system of punishment and reward".

A. Vališová (1998) argues that many of the findings related to the educator's behavior support the idea to find a link between the educational style and personality of an educator. Relationship of an educator and a pupil is actually a function of his/her personality; it is preconditioned mainly by educator's selfconception, his/her relationship to himself/herself. A. Vališová (1998) further claims that the option to understand authoritarian educational style as a reflection of an authoritarian personality is not only a mere speculation based on the external similarity of both concepts. It has been proved that educators achieving high score in authoritarianism are different from other educators. Verifiably, they prefer discipline to the objectives of education. Their idea of the role of an educator is overruled by the need for discipline and their understanding of a pupil is different. According to A. Vališová (1998), it is important that liberal style is not a mathematical opposition to authoritarian educational style. Whereas authoritarianism is characterized by excessive emphasis of the authority, liberal educational style does not necessarily neglect it either.

At school, during the educational process, there is a mutual interaction between the teacher and the pupils. Ch. Kyriacou (1996) argues that the class climate, which a teacher creates, may significantly influence pupils' motivation and their attitude to learning. That is why the teacher's abilities are so important when creating the classroom climate. Regarding the well-being of the pupils, an optimal class climate should be purposive, task-oriented, relaxed, sincere, supportive and sustaining the sense for order. This type of climate supports creating and sustaining positive attitudes of pupils to learning and to their intrinsic motivation. Based on the aforementioned, it can be concluded that the climate in a collective depends on the authority of an educator, on the level of his/her relationship to his/her charge, which is based on the mutual respect and contacts.

Ch. Kyriacou (1996) argues that probably the most important element contributing to the improvement of the quality of education at schools is the promotion of self-esteem and self-confidence of pupils and 


\section{Acta Technologica Dubnicae \\ volume 2, 2012, issue 2}

confidence in their individual learning abilities. Many authors have documented in their works how teachers can damage the self esteem of students by stressing the relative lack of success in comparison to the most outstanding pupils. Such students, then, experience a sense of failure in everything they do, even if their performance is the best one they are capable of. As a result, they are caught in the vicious circle of a series of poor results on one hand and low expectations from teacher about their future work on the other hand.

It is important what value and importance an educator attributes to the views and opinions of the educated. The evaluation should be largely positive, sympathetic, encouraging, and it should not be significantly negative, indelicate, belittling or mocking. The educator significantly influences the behaviour of his/her charge also by his/her approaches to the solutions of their problems, to their errors and to the extend he/she is interested in their problems or progress.

Discipline (lat. disciplina = learning, teaching, education, training, behaviour) means, inter alia, the maintenance of order of the things in work, in an activity, in behavior. The term discipline determines the true and genuine commitment of an individual to the society and to oneself. Discipline belongs to moral qualities, which has evolved within the mankind. It is characterized by features such as binding, volunteerism, awareness and initiative that apply to all human activities. Discipline is based on the intrinsic incentives, external stimuli, laws and standards. Discipline is a specific type of social relation and its mental source is provided by a moral quality of an individual. It takes self-control and selfdiscipline. These two are in a dialectic relation to freedom and necessity, they include basic psychological, sociological and moral principles that an individual has acquired. In the process of education of an adult individual, some basic principles of discipline method are used - the method of persuasion, exercise and practical drill, the method of coercion (e.g.: in penitentiary education) and the method of personal example.

Different civilizations and cultures usually use very different set of standards and norms in all areas of life but, once the standards are set, they must be strictly followed. The basic means of the existence is the obedience. An obedient man unconditionally respects, follows and fulfills the standards and respects the authority of a superior. If one violates the standards, one finds oneself in the conflict; the more one violates these standards, the deeper is the conflict.

The first traces of discipline can be observed in the primitive society. The main objective of the education was to teach the sense of duty, imitation of adults and mutual respect. Disobedience and recklessness were punished by exclusion. The slave society required slavish obedience. Observance of discipline was enforced by harsh corporal punishment. The issue of discipline was in the centre of scholars like Cicero, Seneca and Marcus Aurelius. Cicero regarded the subjection to be a natural human condition. He stressed the obedience, duty, restraint and moderation. Seneca encouraged people in slavish obedience - obedience to Fate was a man's virtue. To protest was vain and sinful. Marcus Aurelius demanded unconditional subjection to applicable laws.

In the feudal society disobedience towards the Church represented the disobedience towards God. Obedience was the fundamental virtue. The Church demanded unconditional fulfilment of norms, selfdenial and humility, obedience to authority. In Middle Ages the Church had abused enormous powers. Christian education enforced harsh discipline, preached humility and obedience, intimidated and physically punished the violation of norms. Ján Hus was, quite on the contrary, an advocate of moral responsibility and reason and its primacy over an order of any authority. His content rating of standards led to the conclusion that man not only has to but one must be disobedient.

J. A. Komenský enriched the concept of discipline with humanistic ideas. "Discipline shall endeavour to create and nourish such a cultivated emotion in those that we nurture for God and the Church just like God asks of his sons entrusted to the school of Christ, to rejoice trembling and to rejoice in Lord, providing in fear and trembling the act of their salvation, that is, the ability to love and revere their teachers, and that they not only like being led to where they need to be led but also that they 


\section{Acta Technologica Dubnicae \\ volume 2, 2012, issue 2}

themselves would eagerly desire so. And such a treatment of emotions cannot be achieved by any other means than by those already insinuated: good examples, kind words, sincere and frank affection and only exceptionally by harder lightning and thundering but even then with severity finally transitioned in as much love as possible“ (Komenský, 1954).

According to Niccolo Machiavelli, obedience could be implemented by the "Prince", who has the right and obligation to act always with regard to his individual benefit and in this regard, he has the right to cancel, reject or follow any kinds of standards. W. Ratke established the idea of a ruler, who, once installed into his office, respects the rights of all. In education, he disagrees with enforcing the discipline, which does not satisfy the needs of a child but feeds the complacency of educators. The Enlightment promotes the human reason and foregrounds an education full of thoughtfulness and attention. At the same time, it is against corporal punishment. J. Locke called for the development of physical and mental discipline that would be focused on self-control and restraint. He perceived the education as a way of improving the human society. Real education, not humiliation, would develop a strong character in a child.

J. J. Rousseau promoted the rights of children; he proposed free and natural education accomplished by empirical experience. He requested an education in accordance with nature. He refused strict discipline and corporal punishment. J. H. Pestaloczi took care of abandoned and street children and educated them. He called for individual approach to everybody. German authors of modern pedagogy set more strict objectives, principles and punishment. I. Kant perceived the discipline to be a moral trait. According to J. F. Herbart, children had to be unconditionally obedient and an educator had to make use of corporal punishment. That was only the external discipline that had never been interiorized. F. W. A. Diesterweg supported independence in thinking and acting; he was against tough education. He requested quality education for educators; he highly appreciated their work. A. S. Makarenko (1974) viewed the discipline as a result of educational process which was manifested in all areas of life. Those who had no discipline were viewed as rebelling against the society. "Indiscipline, undisciplined man in our society is a man against this society. Our discipline, unlike the old one, must be accompanied by awareness, i.e. understanding of what discipline is and why it is necessary" (Makarenko, 1974, p. 27).

The effort of the representatives of the reformed pedagogy was to overcome the pressure that was put on children and to implement humanistic principles. They promoted child's nature and their freedom. To name just a few of them: E. Key, M. Montessori, J. Dewey and E. Key argued that a child should neither be limited nor restrained in the development by any standards, orders or prohibitions. M. Montessori promotes self-discipline based on active discipline. A disciplined individual is not the one who has been artificially restrained and silenced; that is a rag. J. Dewey (in Kominarec, 2006) associated the discipline with interest and persistence. Interest and discipline are mutually related. $\mathrm{He}$ promoted humane approach to children.

"Where an activity takes time, where many means and obstacles lie between its initiation and completion, deliberation and persistence are required. It is obvious that a very large part of everyday meaning of will is precisely the deliberate or conscious disposition to persist and endure in the planned course of action in spite of difficulties and contrary solicitations. A man of strong will, in the popular sense of the words, is a man who is neither a fickle nor half-hearted in achieving chosen ends. His/her ability is executive, i.e. persistently and energetically strives to execute or carry out his/her aims. A weak will is unstable like water. A person who is trained to consider his/her actions, to undertake them deliberately, is disciplined. Add to this ability a power to endure in an intelligently chosen course in face of distraction, confusion, and difficulty, and you have the essence of discipline. Discipline means power at command; mastery of the resources available for carrying through the actions undertaken" (Dewey, 1990 in Kominarec, 2006).

The 50s and the 60s were the period of alternative education. A child was the central pillar of educational activity and the internal discipline related to it. The main strategy of humanistic approach 
revolved around human rights and children's rights. Pupils were taught to respect the rights of others, to tolerate various perspectives, make decisions, and apply leadership. Every historical society has established specific principles and standards of human behaviour in the framework of social relations, which are binding for the society, groups, and individuals in all areas of social life. Discipline is a social phenomenon; it is a sum of social relations expressed in a system of standards, principles and regulations restricting human behaviour and acting in various areas of social life.

R. Olivar (1992) argues that there is no positive agreement among authors regarding the appropriate level of instructing the pupil. It is a well known fact, that there are various attempts on the ideal guidance of pupils; they range from radical authoritarian countercultural experiences to iron-tough discipline at any cost being applied even nowadays in some educational institutions in the West. Results of the studies vary especially regarding the level of instructing, its way of execution, and conditions under which it is provided. Nevertheless, literature clearly states that the frequent use of harsh techniques of instructing, especially of physically aggressive ones, does not help to develop pro-social tendencies but develops aggression in children. This phenomenon is usually explained by the fact that a drastically punished child only rarely sees the consequences of his/her acts; he/she sees only the dramatic punishment manifesting the parental power which may lead to following similar model of his/her behavior in future.

A harsh punishment may prevent repetition of misconduct in a few coming days but it will not prevent it in future. Aggressive guidance activates psychological reaction that produces the opposite tendency. A. Reble (2001) argues that when individuals feel restriction of their freedom or activity, they try to renew it or eliminate the restricting factor. This is often done by an action against the initial impact. The tendency to resist when once raised and maintained can become a permanent attitude which will become universal with other situations and stimuli. It may be the cause of permanent personality disorders. On the other hand, the medium level of empowering combined with a positive reception and acceptance of a child seems to be more favourable for positive guidance of children, especially when they are directed to see the consequences of their deeds. This so-called inductive discipline appears to contribute to the adoption of internalized self-control (Olivar, 1992).

Thus, inductive discipline means directing the attention of a child to the consequences of his/her deeds. This decentralization (distracting the self-centred attention) includes cognitive, but also emotional elements, because it encourages the empathy, which is the fundamental precondition of prosocial behavior. Based on the previous arguments, we can conclude that educator as the authority is a managing element of educational process; he/she creates and directs the required pedagogical situations as initiative conditions of this process. An educator shall awake the awareness of consequences of the deeds in the educated; he/she shall guide them to empathy in order to understand the pain of those they affected by their misdeeds. C. Saladin-Grizivatz (2002) argues that from the pedagogical point of view, any kind of punishment must make sense to the punished. Self-serving sentences showing the omnipotence of an educator are meaningless and they may have a negative impact. The punishment shall never be accompanied by humiliating words. If the punishment is too strict or tough, or postponed, or it seems unfair, it arises anger and sense of unfairness in the punished. Punishments - as well as restrictions - must make sense and they must be adequate.

R. Olivar (1992) views the reward and the punishment as a kind of pro-social stimuli. Perpetual positive stimulation resulted in long-term and generally intensified manifestations of pro-social behavior. The stimulus can be positive and shall follow after some help or service provided; it also can be negative in order to reduce undesirable behavior or eliminate undesirable reactions. Some studies demonstrated positive effect of verbal appraisal, such as "this is really good"; "I'm delighted" which stimulated the willingness to help or to donate. In addition, such appraisal can have a permanent effect. Naturally, there are some concerns regarding the function of positive stimulation mainly in relation to motivation. E. Deci (1975) proved that strong motivation to an activity may cause its devaluation, especially if the behavior does not concentrate on intrinsic value of the activity but on the extrinsic reward. According to the author, this danger does not exist within the social stimulation. 


\section{Acta Technologica Dubnicae \\ volume 2, 2012, issue 2}

R. Olivar (1992) advised the educators to analyze their stimulation methods in various educational situations and to develop their own inventory. He thinks that it is useful for an educator to observe typical situations in which pro-social actions arise spontaneously. These situations should be recorded and appropriately empowered if they arise again. It is likely that such variety of opinions of reward and punishment are to some extend applicable also in prisons or institutions of correction. In this case, the system of reward and punishment is not based on creativity and ingenuity of an educator but it is well-established by law.

The term regime refers to a particular order. It occurs in all areas of social life. M. Kališ (1986) argues that in pedagogy, regime refers to order and schedule of educational activities that take place in certain time and in certain place. A. S. Makarenko (1974) sees the regime as a certain way of organizing the life of the educated performing the function of social control and regulation of behavior. The basic features of a correct regime (its principles), according to A. S. Makarenko, are the following:

- Purposefulness. All forms of regimes must have some sense and some logic, and they must be objectively justified and clear for all parties involved.

- Accuracy. Rules and daily regime shall not tolerate exceptions regarding time, space and method of their fulfilment.

- General obligation. The regime is obligatory for everybody. Exception must correlate with purposefulness. A. S. Makarenko calls the attention to dangerous "elite" that pretends to carry out exceptional tasks in order to avoid the rules of the system.

- Determinacy. Regime can only be followed if it is determined by specific regulations and assigned responsibilities.

J. Vaněk (1972) understands the term regime as the manner of organizing the life cycle and its management at this or that time and place. According to this author, creating and sustaining a regime is based on the following principles:

- Social principles of regime - they are the fundamental principles regulating the social relations within educational groups:

1. Equality principle expresses general binding of the system for everybody.

2. Regulations observance principle requires all violations of the norm to be punished.

3. Standards justification principle requires all members of a group to be convinced of substantiality of the system principles, and recognize them in order to review them.

- Hygienic principles of regime - it is the basic knowledge of hygiene, which is important in overall organization of life of the educated - alternating work and rest, adequate time for personal hygiene, etc.

- Pedagogical principles of regime - it is the fundamental requirement on pedagogical staff when drawing the regime for an educational institution. These principles are:

1. Sustainable positive character of the regime.

2. Well-balanced cognitive, emotional and physical elements.

3. Drawing the system with regard to age and individual needs of the educated.

J. Vaněk (1986) argues that the definition of regime in pedagogy and in penitentiary pedagogy sees the regime as a specific sum of normative requirements regarding social behavior and social relations. These requirements reflect normative value system of the society and general interest of the society in education. Thus, the regime determines the specific activities, behavior and acting and their acceptability in particular time and under particular social conditions. The behavioral requirements are embodied in social norms of the regime. The regime systematically and deliberately influences the personality of the educated with regard to the social norms and regulations. Regime in pedagogy has a regulatory function. Regulatory function is manifested as follows: 


\section{Acta Technologica Dubnicae \\ volume 2, 2012, issue 2}

- The educated are told how to behave to each other, to educational staff, and to other people they meet.

- Specific activities are scheduled. Formally, this function is manifested in the daily timetable, which specifies how and when a particular activity is carried out.

- Rights and obligations of the educated are determined and methods of application and performance are stated.

- There are enumerated sanctions for violation of the set standards.

Regime is a method of ethical education; its immediate educational objective is to teach discipline as a moral trait of personality. Disciplinary rewards and punishments are the direct form of discipline implementation. On the contrary, regime is an indirect form. The essence of the regime lies in the systematic and intentional use of social and regulatory impact of the collective to an individual. This form supports the active participation of prisoners in organizing their life; it is deliberately implemented in community systems of collective education regarding the elimination of negative impact of criminal subculture standards and, in parallel, implementing positive influence of social relations in groups. The strategy, known as "parallel action pedagogy" was developed by A. S. Makarenko (1974). An educator can combine direct and indirect form of discipline implementation in order to influence the prisoners. Each form is specific; the specifications are manifested mainly in the approach to the prisoners with regard to educational objectives as well as to intrinsic and extrinsic conditions of education.

\section{Literature}

CZAPÓW, C.: Resocializační pedagogika. Bratislava: SPN, 1981.

DECI, E.: Intrinsic motivation. New York: Plenum Publishing Co., 1975.

DIESTERWEG, F. W. A.: Príručka vzdelania pre nemeckých učitel'ov. In: PETLÁK, E.: V̌̌eobecná didaktika. Bratislava: IRIS, 1996.

KALIŠ, M.: Základy pedagogiky režimového ovplyvňovania. In: Metodické listy č. 2, Bratislava: Ministerstvo spravodlivosti SSR, 1986.

KOMENSKÝ, J. A.: Vel'ká didaktika. Bratislava: SPN, 1954.

KOMINAREC, I. et al.: Základy pedagogiky. Prešov: FHPV PU v Prešove, 2006.

KOSOVÁ, B.: Rozvoj osobnosti žiaka. Prešov: Rokus, 2000.

KOVÁČ, D.: Teória všeobecnej psychológie. Bratislava: SAV, 1985.

KYRIACOU, Ch.: Klíčové dovednosti učitele. Praha: Portál, 1996.

MAKARENKO, A. S.: Metodika organizácie výchovného procesu. Praha: SPN, 1974.

OLIVAR, R.: Etická výchova. Bratislava: Orbis Pictus Istropolitana, 1992.

PETTY, G.: Moderní vyučování. Praha: Portál, 1996.

RYS, S.: Hospitace v pedagogické praxi. Bratislava: SPN, 1975.

SALADIN-GRIZIVATZ, C.: Rodičovská autorita. Praha: Portál, 2002.

VALIŠOVÁ, A. et al.: Autorita ako pedagogický problém. Praha: Karolinum, 1998.

VANĚK, J.: K biologickým a psychologickým zretelom výchovy. Praha: SNP, 1972.

VIŠŇOVSKÝ, L.: Teória výchovy. Banská Bystrica: PF UMB, 1998.

VIŠŇOVSKÝ, L'. et al.: Základy školskej pedagogiky. Bratislava: IRIS, 2001.

Výchova a vzdelávanie dospelých - ANDRAGOGIKA - terminologický a výkladový slovník 7. Bratislava: SPN, 2000. 